\title{
무상원조 심사평가체제 구축을 위한 정책조사단 보고 (2)
}

1. 무상원조 심사평가체제구축을 위한 정책조사 단(단장 박강호 국제 경제국 심의관, 현 $\mathrm{KOICA}$ 이사)은 6.22 (목) 스웨덴을 방문, 스웨덴 외교부 Torgy Holmgren개발정책국장, Karin Johanson 개발협력관리 및 평가국 부국장 등 과 면담하고 스웨덴의 $\mathrm{ODA}$ 평가시스템을 파악 · 조사한 바 동 주요내용 및 시사점을 아래 보고함.

\section{가. 스웨덴의 ODA시행체계}

- 대외원조관련 주요정책결정은 외교부가 담 당하며 구체적인 집행은 외교부산하의 대외 개발협력청(SIDA)이 담당

- SIDA의 예산은 외교부에 포함되어 외교 부 전체예산의 약 $50 \%$ 에 달함

- 대외원조를 외교정책과 긴밀히 연계

- 재외공관에 SIDA직원을 파견하여 해당국의 대외지원업무를 감독

- 특히 $\mathrm{SIDA}$ 는 대부분의 ODA사업을 $\mathrm{NGO}$ 를
통해 실시

- NGO 사업의 약 $80 \%$ 를 SIDA가 지원

\section{나. ODA 평가시스템}

- 스웨덴국제개발청(SIDA)의 평가감사국 (UTV)에서 프로젝트 및 분야별, 국별 프로 그램을 대상으로 사후 평가 위주 실시

- 또한 평가의 독립성 확보, 성과중심 관리제 도의 도입 및 개발 원조 사업에 대한 국민의 이해 증대를 위해, 의회 결정에 따라 독립된 평가기관인 스웨덴 개발평가청(Swedish Agency for Development Evaluation)이 최근에 설립되어 국별 평가 및 다자기구를 통한 원조 평가 업무를 담당 ※ 스웨덴 개발평가청

- 개요

: 정부출연기관으로서 국제개발협력의 전문가 분석과 평가 이행 및 결과 확산 을 제고하기 위해 2006.1.1 설립 
- 목적

: 일반 국민을 포함하는 구체적 목표그룹 에게 국제개발협력의 조직, 방향, 규모,

구성 및 효과에 대해 적정, 적시의 종합 적인 분석을 제공

- 조직 : 청장 외 직원 11 명

- 이사회

: 연간 보고서와 예산의 승인 및 $\mathrm{SADEV}$ 활동을 감독하며 독립적인 민간인사 6 명 및 청장을 포함한 7명으로 구성

\section{다. 평가과정}

- $\mathrm{SADEV}$ 는 7명의 학계, 민간 전문가 등으로 구성된 이사회 중심으로 운영되며, 자체적으 로 평가대상, 평가계획을 수립, 실시하며 그 결과를 정부, $\mathrm{SIDA}$ 등과 공유

- SIDA 평가감사국은 연간 평가 계획을 작성 이사회에 보고하며, 평가 결과를 이사회에 보고하고 이사회는 이를 검토, 향후 원조 추 진 방안을 정부측에 제시

- 정부결정 후 $\mathrm{SIDA}$ 에서 집행

\section{라. 평가 파트너쉽 및 능력 배양}

\section{(capacity building)}

- World Bank 등 다자기구와의 공동평가 증 가하고 있으며 다른 공여국과의 협력도 증대

- 평가 수행 시 수원국 출신의 전문가를 활용
함으로써, 평가의 객관성과, ownership을 제고하고 자체 평가능력 향상에도 기여

\section{마. 평가결과 활용}

- 평가결과를 적극 공개

- ODA가 꾸준히 증액되어 이에 대한 납세 시민의 관심 증대

a 공개방법

- 관계기관에 배포할 뿐만 아니라 간행물 발간, 인터넷 등을 통해 배포

- 세미나 개최, 연수, 자문, 데이터베이스화

\section{2. 시사점}

- 스웨덴에서는 1990년대 이후 ODA의 증가 에 따른 성과여부에 대한 관심확대, 특히 국 회 및 시민사회의 $\mathrm{ODA}$ 성과 분석요구가 증 대함에 따라 독립적인 평가기구의 설치필요 성이 제기되었고 결국 금년 1월 독립적인 평 가기관(SADEV)이 설치됨

- 동 $\mathrm{SADEV}$ 는 스웨덴 대외원조의 대외원조 성과에 대한 전반적인 평가 및 향후 원조 방 향을 제시하고 있는바, 우리나라의 국제개발 협력위원회 평가소위운용과 관련 참고가 될 수 있을 것임.

[자료: 주스웨덴대사관] 